\title{
THE PRICE OF GROWTH*
}

$\mathrm{T}$ HE growth of output is now receiving more emphasis than ever before. This is so in the rich countries as well as in the poor; it is true of the Communist world even more than of the West. Paradoxically the affluent society has been much criticized in the West. Growth and affluence are both emotive words, one good and the other bad.

There are several reasons for the increased emphasis on growth. Competition has been stimulated by international league tables prepared by economic statisticians, who may be the most subfusc of agitators, but are not the least powerful. The needs of national security afford another reason. Another is the reluctant but growing recognition that little can be achieved by the redistribution of income; the new emphasis therefore reflects a new realism which may imply a less apocalyptic view of social improvement. Moreover, the high degree of success in preventing unemployment since the War has diverted attention to the importance of raising productivity.

Growth often involves a price. How much should be sacrificed in other directions for the sake of how much more growth? A more rapid growth of output must not be described as an economic objective while personal freedom or defence or the preservation of local communities are held to be non-economic objectives. This is a misuse of terms. Economics deals with means not ends. Formal welfare analysis has been cautious but modern applied economics is less so. It must be recognized that genuine conflicts involving value judgements will be encountered. If they do nothing else, economists can at least help to disentangle the issues, and to indicate where possible the orders of magnitude, and to point out where the ultimate value judgements must be made.

It has been held that growth would be fostered if the Trade Unions were to be emasculated, as they have been in the U.S.S.R. But we would hesitate in the West before overthrowing one of the most effective forms of countervailing power confronting the State. Of course, the factual assumptions need to be examined in detail and the possibility of a third alternative investigated. But sacrifices may sometimes have to be accepted. Cost-inflation, 'stop - start' and a slower rate of growth may result from a refusal to enforce an incomes policy if such a policy is not accepted voluntarily. This should be borne in mind in making international comparisons.

If growth were to be given the emphasis in Great Britain which it receives in Communist countries, the best managers might not be greatly affected but the weaker managers would be: and the inquisitions and the punishments which would accompany such a policy would represent, in a broader sense, a loss of social efficiency. Another question is how far equality should be sacrificed for the sake of growth. Even if rapid growth does not mean that there are losers as well as gainers, the gap between rich and poor may sometimes widen domestically or internationally. Would more equality be preferred even if everyone were poor? Regional policy affords another example : rapid growth is not consistent with

* Substance of presidential address delivered by Prof. T. Wilson, Professor of Political Economy, University of Glasgow, on September 2 before Section F (Economics) of the British Association meeting in Aberdeen. bolstering up industry in every location whether suitable or otherwise.

The needs of growth will often conflict with other needs, but these conflicts must not be exaggerated. Rapid growth will often be the best way of solving other problems as well as raising the average level of income. For example, growth in the West has clearly drawn much of the sting from inequality, or again, within the less-prosperous areas, there may be potential zones of growth and the national objective of higher output may coincide with local needs. Sometimes an apparent conflict reflects a failure to appreciate the facts. It would be foolish to direct labour into particular occupations merely for the sake of growth; airection is inefficient, and individual freedom would often be sacrificed for no purpose. Moreover, the quantities must be examined. Thus the fashionable claim that for the sake of growth Britain must spend less abroad on aid and defence ignores the orders of magnitude and implies a disproportionate sacrifice for a modest gain.

Finally, the role of the economist in these matters was reviewed by Prof. Wilson. He showed how the econumist can break up complex propositions into their consistent parts: measurable factual considerations; non-measurable factual considerations; considerations of a kind not professionally studied by economists such as public health or strategy; ultimate value judgements. The value judgements will often be present, but it is suggested that they will give rise to less disagreement than is frequently supposed provided the rest of the analysis has been adequately performed.

\section{THE SUN AND THE EARTH'S ENVIRONMENT}

Geophysics

The Earth's Environment--Lectures delivered at Les Houches during the 1962 Session of the Summer School of Theoretical Physics, University of Grenoble. Edited by C. DeWitt, J. Hieblot and A. Lebeau. Pp. xiv +624. (New York and London: Gordon and Breach, 1963.) 10.50 dollars, cloth; 8.50 dollars, paper.

Physique Solaire et Géophysique

Par Prof. A. Dauvillier. Pp. $362+1$ plancho. (Paris: Masson et Cie., 1962.) $72 \mathrm{NF}$.

URING the past few years there has been intensive study of the Earth's upper atmosphere and of that part of the Sun's outer envelope which lies beyond it. The fascination of this field of research, and the availability of new facts resulting from experiments in rockets and satellites, have led to a voluminous outpouring of publications, some important and some trivial. The writings are so numerous that even those closely interested in the subject find it difficult to follow the advance of their own little speciality; those studying the subject for the first time find it unusually confusing. Any writings which aim at summarizing the results either for the expert or for those starting research on the subject are particularly welcome, and deserve close examination to decide just how useful they are.

Geophysics: The Earth's Environment contains chapters based on a series of lectures delivered at Les Houches during the 1962 session of the summer sehool of theoretical physics, the University of Grenoble. 